\title{
Evaluation of Flour and Starch Qualities from Three Cassava Varieties for Ethanol Production Using a Novoenzyme and a Strain of Dried Saccharomyces cerevisiae (Yeast)
}

\author{
HA, Etudaiye ${ }^{1}$, UJ, Ukpabi ${ }^{1,2}$, E, Egesi ${ }^{1}$, and A, Ikpeama ${ }^{1}$ \\ ${ }^{1}$ National Root Crops Research Institute (NRCRI), Umudike, PMB 7006, Umuahia, Abia State, Nigeria \\ ${ }^{2}$ Center for Food Technology and Research (CEFTER),Benue State University, Makurdi, Nigeria \\ Email: etudaiyehuss@yahoo.com
}

\begin{abstract}
Flours and starches were processed from three cassava varieties namely TMS 98/0505, TMS 419 and NR 8082. The flours and starches were fermented employing Termamyl Type L Novoenzyme (an alpha amylase), glucoamylase from A.niger and dried form of Saccharomyces yeast. The flours and starches were analysed for moisture/dry matter, fibre, amylose and amylopectin contents. Slurries obtained were analysed for glucose contents, $\mathrm{pH}$, total titratable acidity (TTA) and temperature during $72 \mathrm{hrs}$ of fermentation. The ethanol yield of the flours and starches were determined. Significant differences $(\mathrm{P}<0.05)$ were found among the cassava flours/starches with respect to moisture/dry matter, fibre, amylose and amylopectin contents. The ethanol yield of the flours and starches tended to be dependent on their amylose contents. Correlation between amylose and ethanol yield were $96.20 \%$ (flour) and $86.39 \%$ (starch). The yields of ethanol from filtrates of slurries obtained from fermented cassava starch samples were higher than that of the flour samples. Ethanol yields from starch of TMS 98/0505, TMS 419 and NR 8082 were 20.49\%, 18.98\% and 18.21\%, respectively. Those of flour samples were $14.01 \%, 14.04 \%$ and $12.56 \%$, respectively. The glucose contents and the $\mathrm{pH}$ of the fermenting slurries of the flours and starches decreased as fermentation progressed, whereas their TTA and temperatures generally increased. Ethanol yields from starch of TMS 98/0505 were the highest when compared with the other varieties used. The study recommends cassava variety TMS 98/0505 in ethanol production.
\end{abstract}

Keywords: cassava, flour, starch, fermentation, ethanol yield.

\section{Introduction}

The markets for domestic and industrial starches are expanding and cassava (Manihot Esculenta Crantz) is mostly satisfied as one of the crops. Cassava is particularly important as a source of starch in tropical and sub-tropical regions.

Starch and flour, the main plant carbohydrates are the most important plant derivatives used by man. They have unlimited importance in industry and food and can be modified to suit various applications using in-expensive methods making them ideal for a number of purposes [1]. Starch consists of two polysaccharides, the linear molecule, amylose and a highly branched molecule, amylopectin.

Termamyl, an $\alpha$-amylase isolated from Bacillus licheniformis, a soil bacterium. This enzyme hydrolyses 1, 4- $\alpha$-glucosidic linkages in starch and possesses a high degree of heat stability. It is used for the continuous liquefaction of starch at temperatures of up to $105-110^{\circ} \mathrm{C}$, breaking them rapidly to dextrins and oligosaccharides. Amyloglucosidase (AMG), an exo-1, 4- $\alpha$-Dglucosidase (glucoamylase) was obtained from a selected strain of the fungus, Aspergillus niger. This enzyme hydrolyses 1, 4- and 1, 6- $\alpha-$ glucosidic linkages in liquefied starch in stepwise manner from the non-reducing end of the substrate molecules [2].

Bio-ethanol is a strategic raw material with wide range of applications in food, pharmaceutical, cosmetic, and petrochemical industry [3]. Also, it has been used as a modern biofuel, applied directly as a gasoline improver or gasoline substituent [4], or in the form of ETBE (ethyl tertiary buthyl ether), to substitute for currently added synthetically-produced octane enhancers [5], and in ethanol-diesel blends with particular purpose to reduce the emissions of exhaust gasses[6]. Works have been carried out by comparing the yields of ethanol obtained from starches and flours of sweetpotato varieties [7]. The 
objective of this work is to evaluate the quality of starches and flours of different cassava varieties for ethanol production.

\section{Materials and Methods}

\subsection{Source of Raw Materials}

Fresh roots of three (3) cassava varieties TMS 98/0505, TMS 419 and NR 8082 were harvested at about 11 months old from field trial of cassava Programme, National Root Crops Research Institute, Umudike. The Cassava Mosaic Disease (CMD) resistant varieties (TMS 98/0505 and TME 419) were developed for foods, feed and industrial use [8].

\subsection{Source of Enzymes}

Termamyl Type L Novoenzyme AYN02215 (an alpha amylase), glucoamylase from A.niger and dried form of Saccharomyces yeast (BP1422-500,Fischer Scientific, Pittburgh, PA) were obtained from the International Center for Tropical Agriculture (CIAT), Palmira, Colombia.

\subsection{Starch Isolation from Cassava Roots}

Starch isolation was done with the recommended method of [9]. Freshly cut yam pieces were suspended in a tap water in a $2 \mathrm{~L}$ capacity electric blender. The slurry was filtered through a $100 \mu \mathrm{m}$ sieve. The starch was allowed to settle in a $200 \mathrm{ml}$ beaker and refrigerated for 12 hours at $4^{\circ} \mathrm{C}$. The supernatant was decanted off and wet starch sample was dried in an oven with fan- forced ventilation at $40^{\circ} \mathrm{C}$ for 2 days. The starch constituted $100 \%$ particles that passed through a $425 \mu \mathrm{m}$ sieve.

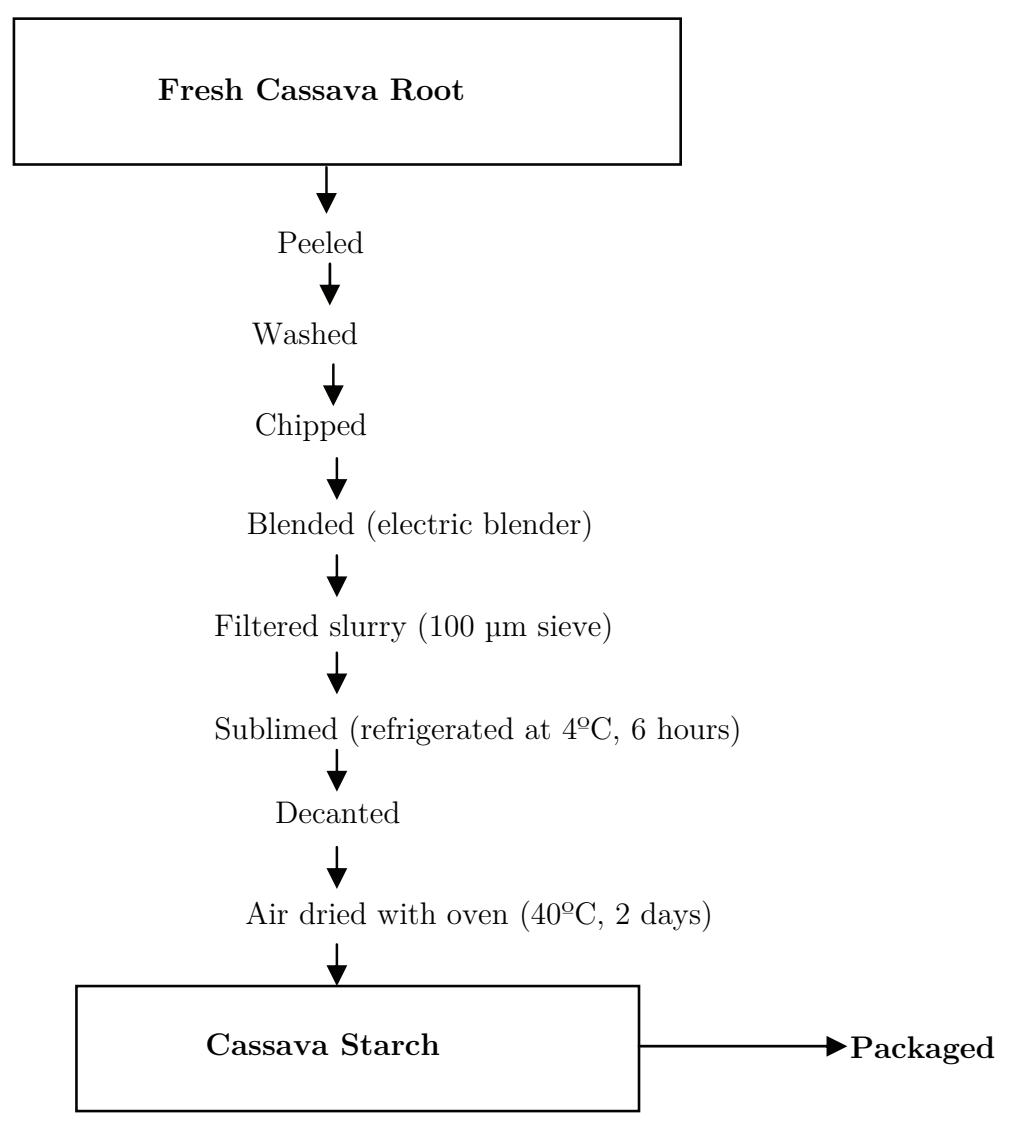

Figure 1. Flow chart of starch isolation from fresh cassava root 


\subsection{Processing of Root into Flour}

The method of [10] with some modification was used. Freshly cut pieces of cassava root were spread on a stainless steel tray and sun-dried for about 72 hours. The sundried cassava chips were further oven dried with a fan- forced ventilation at $40^{\circ} \mathrm{C}$ for 24 hours. The dried chips were milled, sieved and stored with low density polyethylene (LDPE) bags for further analysis.

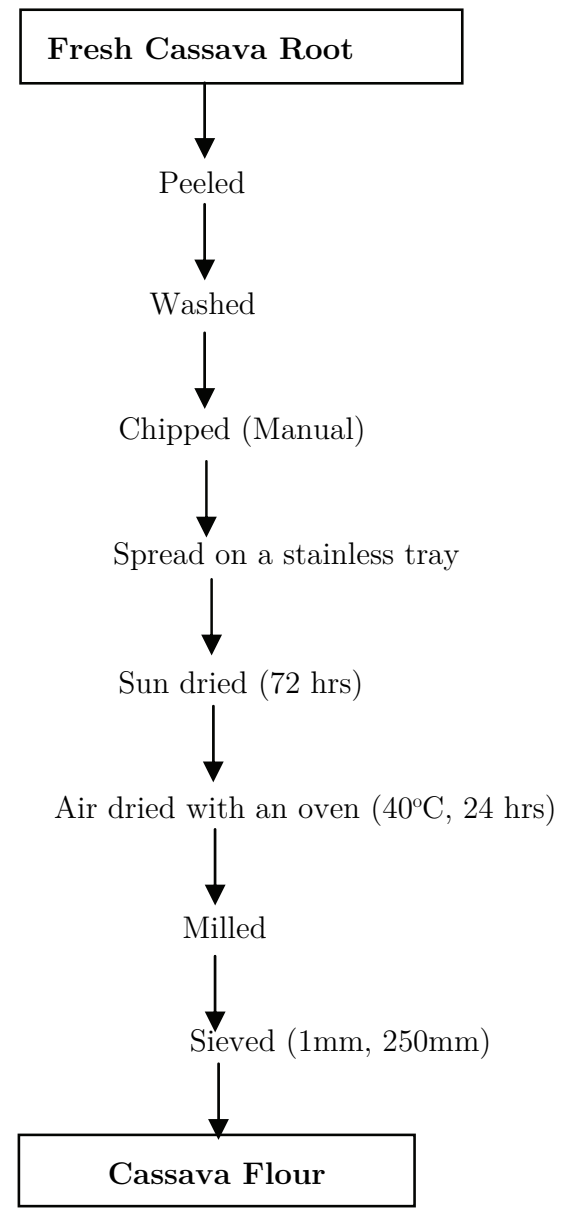

Figure 2. Flow chart for processing of cassava root into flour

\subsection{Determination of Moisture and Dry Matter Contents}

Moisture and dry matter contents of flour and starch samples were determined by the [11]. A Clean weighing petri dish was placed in an oven and dried at $80^{\circ} \mathrm{C}$ for about $30 \mathrm{~min}$, cooled in a dessicator and weighed $\left(\mathrm{W}_{\mathrm{o}}\right)$. About $2 \mathrm{~g}$ of the each sample was weighed into the petri dish and re-weighed (b). The Petri dish with the sample was dried in an oven at $70^{\circ} \mathrm{C}$ for $5 \mathrm{hr}$, cooled in a desiccator. The procedure was repeated until a constant weight (c) was achieved.

\section{Calculation:}

$\mathbf{W}_{\mathbf{o}}=$ Weight of moisture can

$\mathbf{b}=$ Weight of moisture can + sample

$\mathbf{c}=$ weight of moisture can + dried sample

$\mathbf{b}-\mathbf{c}=$ Weight of dried sample

$\mathbf{b}-\mathbf{W}=$ Weight of wet sample $\underline{\mathrm{b}-\mathrm{w}}$

$\%$ Moisture content $(\mathrm{MC})=\mathrm{b}-\mathrm{c} \times 100$

$\%$ Dry matter content $(\mathrm{DM})=100-\mathrm{MC}$ 


\subsection{Determination of Crude Fibre}

The method of [11] was used. About 2 grams of flour/starch samples were extracted with n-hexane. This was transferred into a $1 \mathrm{~L}$ flask. About $200 \mathrm{ml}$ of $1.25 \%(\mathrm{v} / \mathrm{v})$ boiling Sulphuric acid was added and the flask was placed on a hot plate and boiled for $30 \mathrm{~min}$. The content was filtered and the residue was washed with 50-70 ml of distilled water. The residue was removed and $200 \mathrm{ml}$ boiling $1.25(\mathrm{w} / \mathrm{v}) \mathrm{NaOH}$ was added and boiled for $30 \mathrm{~min}$. The content was filtered and the residue was washed with distilled water. The residue was then transferred to an ashing dish and dried at $130^{\circ} \mathrm{C}$ for $2 \mathrm{~h}$, cooled in a dessicator and weighed. This was then ignited at $600^{\circ} \mathrm{C}$, cooled and reweighed. The difference in weight was taken as crude fibre.

\subsection{Hydrolysis/Fermentation with Conventional Enzymes}

A 50 g laboratory dry grind procedure was used. Processing differences from the Termamyl Type L Novoenzyme AYN02215 (an alpha amylase) procedure were the enzymes and liquefaction temperature used. Samples were liquefied by increasing slurry temperature to $90^{\circ} \mathrm{C}$ and adding $140 \mathrm{ml}$ of the alpha amylase enzyme at $\mathrm{pH}$ 6.0. The slurry was maintained at $90^{\circ} \mathrm{C}$ for $2 \mathrm{hr}$ with continuous agitation at 120 rpm. After $2 \mathrm{hr}$, the slurry temperature was decreased to $30^{\circ} \mathrm{C}$ and the $\mathrm{pH}$ was adjusted to 4.0 with $5 \mathrm{M}$ Sulphuric acid solution. Simultaneous saccharification and fermentationwas performed by adding $140 \mathrm{ml}$ of glucoamylase, S. cerevisiae yeast $(0.01 \mathrm{~g} / \mathrm{g}$ starch) and yeast supplements to the slurry. The slurry was maintained at $30^{\circ} \mathrm{C}$ for $72 \mathrm{hr}$ with constant agitation at $100 \mathrm{rpm}$.

\subsection{Laboratory Analysis}

At constant weights (120g) of the fermenting mash, each sample of flour and starch from each variety was analyzedfor $\mathrm{pH}$, titratable acidity (TTA) and mash temperature [7].

\subsection{Determination of $\mathrm{pH}$ and Titratable Acidity (TTA)}

The $\mathrm{pH}$ of the fermenting media was determined by taking a $10 \mathrm{ml}$ portion of the slurries ( $0 \mathrm{hr})$ and (72 $\mathrm{hr}$ during fermentation) and their $\mathrm{pH}$ determined using a HANNA pH meter (HANNA Instruments, model HI96107, Italy). The TTA (expressed as percentage lactic acid) of the fermenting media was determined by titrating $25 \mathrm{ml}$ of the fermenting medium against $0.1 \mathrm{~N} \mathrm{NaOH}$. The TTA in each sample was determined as the product of the titre value and 0.09 which is the lactic acid factor [13][14].

\subsection{Determination of Mash/Slurry Temperature}

Temperature of fermented slurries of starch and flour samples was determined using [11].

\subsection{Determination of Amylose and Amylopectin}

Amylose content in the flour and starch samples were measured following standard procedures [15]. Flour/Starch granules were first dispersed with ethanol and then gelatinized with Sodium Hydroxide. An aliquot was then acidified and treated with an iodine solution, which produces blue-black stain coloration. The colour intensity, which is related to amylose content, was then measured with a spectrophotometer and compared with standard curves, obtained using purified amylose and amylopectin extracted from potato tubers. Three different quantifications per flour/starch sample were made, and mean values were then calculated. Amylose content was estimated thus:

Amylose content $(\%)=(3.06) \times \mathrm{A} \times 20$

where $\mathrm{A}=$ Absorbance value

$$
\text { Amylopectin }=100-\text { Amylose content }
$$

\subsection{Estimation of Reducing Sugar (Glucose)}

The method of [15] was used. Estimation of reducing sugar (glucose) was done by dinitrosalicylic 
method. Glucose standard solutions in $0.05 \mathrm{M}$ acetate buffer ( $\mathrm{pH} 4.8$ ) ranging from 0.6-4.00 $\mu \mathrm{mol} / \mathrm{ml}$ were prepared. $1 \mathrm{ml}$ of each standard was added to separate tubes. Blank was made by adding $1 \mathrm{ml}$ of $0.05 \mathrm{M}$ acetate buffer ( $\mathrm{pH}$ 4.8) in a separate tube. Slurries obtained from fermented flour/starch samples at different periods (hours) were collected into different test tubes. To each tube, $1 \mathrm{ml}$ of $0.05 \mathrm{M}$ acetate buffer ( $\mathrm{pH}$ 4.8) were introduced and mixed. About 3ml DNS reagent was introduced into each of the test tubes and mixed well. The tubes were placed in boiling water for 5 minutes, cooled to room temperature and absorbance measured at $540 \mathrm{~nm}$.

\subsection{Statistical Analysis}

Data obtained were subjected to statistical analysis with the aid of Statistical Analytical System (SAS) software, version 8, 2009. Analysis of variance (ANOVA) was done. Mean separation by Fischer LSD to determine significant difference (P at 0.05) was carried out [16].

\section{Results and Discussion}

Table 1. Biochemical properties of cassava flour and starches for ethanol production

\begin{tabular}{cccccc}
\hline Cassava & \multicolumn{5}{c}{ Flour } \\
\cline { 2 - 6 } variety & Moisture (\%) & Dry matter (\%) & Fiber (\%) & Amylose (\%) & Amylopectin (\%) \\
\hline TMS 98/0505 & $8.73 \mathrm{c}$ & $91.27 \mathrm{a}$ & $1.08 \mathrm{ab}$ & $18.74 \mathrm{a}$ & $81.16 \mathrm{c}$ \\
TME 419 & $9.60 \mathrm{a}$ & $90.40 \mathrm{c}$ & $1.12 \mathrm{a}$ & $18.53 \mathrm{~b}$ & $81.47 \mathrm{~b}$ \\
NR 8082 & $9.45 \mathrm{~b}$ & $90.55 \mathrm{~b}$ & $1.06 \mathrm{~b}$ & $17.93 \mathrm{c}$ & $82.07 \mathrm{a}$ \\
LSD (0.05) & 0.04 & 0.05 & 0.06 & 0.07 & 0.04 \\
\hline Cassava & \multicolumn{5}{c}{ Starch } \\
variety & Moisture (\%) & Dry matter (\%) & Fiber (\%) & Amylose (\%) & Amylopectin (\%) \\
\hline TMS 98/0505 & $5.76 \mathrm{c}$ & $94.24 \mathrm{a}$ & $1.26 \mathrm{a}$ & $20.28 \mathrm{a}$ & $79.32 \mathrm{c}$ \\
TME 419 & $6.18 \mathrm{a}$ & $93.82 \mathrm{c}$ & $0.30 \mathrm{a}$ & $20.19 \mathrm{~b}$ & $79.81 \mathrm{~b}$ \\
NR 8082 & $5.84 \mathrm{~b}$ & $94.16 \mathrm{~b}$ & $0.25 \mathrm{a}$ & $19.82 \mathrm{c}$ & $80.08 \mathrm{a}$ \\
LSD (0.05) & 0.05 & 0.07 & 0.07 & 0.04 & 0.03 \\
\hline
\end{tabular}

Mean values across columns with different superscripts are significantly different $(\mathrm{p}<0.05)$

Table 2. Ethanol yield (v/w) during 72 hours fermentation of cassava flours and starches

\begin{tabular}{ccc}
\hline Cassava & \multicolumn{2}{c}{ \% Ethanol yield $(\mathrm{v} / \mathrm{w})$} \\
\cline { 2 - 3 } variety & Flour & Starch \\
\hline TMS 98/0505 & $14.01 \mathrm{a}$ & $20.49 \mathrm{a}$ \\
TME 419 & $14.04 \mathrm{a}$ & $18.98 \mathrm{~b}$ \\
NR 8082 & $12.56 \mathrm{~b}$ & $18.21 \mathrm{c}$ \\
LSD (0.05) & $\mathbf{0 . 4 9}$ & $\mathbf{0 . 2 0}$ \\
\hline
\end{tabular}

Mean values across columns with different superscripts are significantly different $(\mathrm{p}<0.05)$

Table 1 shows values of some biochemical parameters of flours and starches from cassava varieties for ethanol production. Moisture contents (MC) were low and ranged from 8.77- 9.60\%. Dry matter contents (DM) were high and ranged from 90.40-91.27\%. Values of moisture and dry matter were respectively lower and higher than the reports of [15]. Fibre ranged from 1.06-1.12\%. Amylose contents were in appreciable levels and ranged from 17.93-18.74\%. There was a significant difference $(\mathrm{p}<0.05)$ in the parameters determined. Biochemical parameters of starches from cassava varieties for ethanol production showed that MC were low and ranged from 5.76- 6.18\%. DM contents were high and ranged from 93.82-94.24\%. Fibre ranged from 0.25-0.30\%. Amylose contents were in appreciable levels and ranged from 19.82-20.28\%. Values of amylose were within the range of values reported by [17] in a work titled crystalline and pasting properties of cassava starch as influenced by its molecular properties and that of [17][18]. There was a significant difference $(\mathrm{p}<0.05)$ in the parameters determined. Table 2 
shows ethanol yields of flours and starches from cassava varieties after $72 \mathrm{hrs}$ fermentation. Ethanol yield was highest from the flour of cassava variety TME $419(140.4 \mathrm{~g} / \mathrm{L})$ and highest in the starch of cassava variety TMS 98/0505(204.9g/L). However, there was no significant difference $(\mathrm{p}>0.05)$ in the ethanol yields from flours of cassava varieties TME 419 and TMS 98/0505. There was a significant difference $(\mathrm{p}<0.05)$ in the ethanol yields from starches of three cassava varieties used. Table 3 shows some changes in the physico-chemical parameters during 72 hours fermentation of cassava flour and cassava starch slurries. Glucose, $\mathrm{pH}$ and temperature of the slurries decreased as fermentation progressed while the TTA and temperatures decreased. Changes in these parameters are an indication of yeast and enzyme activities and potentials. This is in line with the report of [7] in a work titled effect of variety and influence of granular starch hydrolyzing enzyme and yeast on the yield of ethanol generated from sweetpotato flours and starches. However, previous work as referenced focused on sweetpotato starch and flour while this is on cassava starch and flour. Also, values of $\mathrm{pH}$ and TTA were similar to the previous values reported by [19] titled enzymatic production of ethanol from cassava starch using two strains of Saccharomyces cereviciae. Tables 4 shows positive correlation between amylose and ethanol yields from flour and starch samples [20]. High amylose content gives rise to high ethanol yield and this can be used as a practical approach in determining the production potential and marketability of ethanol [7][21]. Ethanol yield is affected by bioavailability of starch may differ among varieties or cultivars [22]. Starch is a polymer of glucose, composed of genetically determined ratios of amylose and amylopectin. Different temperatures during fermentation conform with [23] that starches from different botanical sources or from the same source but with different amylose contents may have very different fermentation temperatures and ranges.

Table 3. Hydrolytic and fermentation changes in cassava flour and starch for ethanol production

\begin{tabular}{|c|c|c|c|c|c|c|c|c|c|c|c|c|}
\hline \multirow{3}{*}{$\begin{array}{l}\text { Cassava } \\
\text { variety }\end{array}$} & \multicolumn{12}{|c|}{ Flour } \\
\hline & \multicolumn{3}{|c|}{ Glucose (\%) } & \multicolumn{3}{|c|}{$\mathrm{pH}$} & \multicolumn{3}{|c|}{ Total titratable acidity (\%) } & \multicolumn{3}{|c|}{ Temperature $\left({ }^{\circ} \mathrm{C}\right)$} \\
\hline & $0 \mathrm{hr}$ & $72 \mathrm{hr}$ & Changes & $0 \mathrm{hr}$ & $72 \mathrm{hr}$ & Changes & $0 \mathrm{hr}$ & $72 \mathrm{hr}$ & Changes & $0 \mathrm{hr}$ & $72 \mathrm{hr}$ & Changes \\
\hline TMS 98/0505 & 8.90 & 3.20 & $(-)$ & 4.90 & 3.16 & $(-)$ & 0.58 & 0.78 & $(+)$ & 29.00 & 30.00 & $(+)$ \\
\hline TME 419 & 8.63 & 2.94 & $(-)$ & 4.85 & 3.42 & $(-)$ & 0.52 & 0.70 & $(+)$ & 28.00 & 32.00 & $(+)$ \\
\hline NR 8082 & 8.16 & 2.70 & $(-)$ & 4.92 & 3.40 & $(-)$ & 0.48 & 0.67 & $(+)$ & 29.00 & 32.00 & $(+)$ \\
\hline \multirow{3}{*}{$\begin{array}{l}\text { Cassava } \\
\text { variety }\end{array}$} & \multicolumn{12}{|c|}{ Starch } \\
\hline & \multicolumn{3}{|c|}{ Glucose $(\%)$} & \multicolumn{3}{|c|}{$\mathrm{pH}$} & \multicolumn{3}{|c|}{ Total titratable acidity $(\%)$} & \multicolumn{3}{|c|}{ Temperature $\left({ }^{\circ} \mathrm{C}\right)$} \\
\hline & $0 \mathrm{hr}$ & $72 \mathrm{hr}$ & Changes & $0 \mathrm{hr}$ & $72 \mathrm{hr}$ & Changes & $0 \mathrm{hr}$ & $72 \mathrm{hr}$ & Changes & $0 \mathrm{hr}$ & $72 \mathrm{hr}$ & Changes \\
\hline TMS 98/0505 & 8.76 & 2.85 & $(-)$ & 4.65 & 2.94 & $(-)$ & 0.58 & 0.78 & $(+)$ & 28.00 & 32.00 & $(+)$ \\
\hline TME 419 & 8.45 & 2.70 & $(-)$ & 4.74 & 3.25 & $(-)$ & 0.52 & 0.70 & $(+)$ & 29.00 & 30.00 & $(+)$ \\
\hline NR 8082 & 7.62 & 2.56 & $(-)$ & 4.85 & 3.34 & $(-)$ & 0.48 & 0.67 & $(+)$ & 28.00 & 31.00 & $(+)$ \\
\hline
\end{tabular}

Table 4. Correlation coefficient analysis of dry matter, amylose and ethanol yield of cassava flours and starches

\begin{tabular}{c|ccc|ccc}
\hline \multirow{2}{*}{ Parameters } & \multicolumn{3}{|c|}{ Flour } & \multicolumn{3}{c}{ Starch } \\
\cline { 2 - 7 } & Dry matter (\%) & Amylose (\%) & Ethanol yield (\%) & Dry matter (\%) & Amylose (\%) & Ethanol yield (\%) \\
\hline Dry matter(\%) & 1.00 & 0.57 & 0.34 & 1.00 & 0.15 & 0.36 \\
Amylose(\%) & $* * *$ & 1.00 & 0.96 & $* * *$ & 1.00 & 0.86 \\
Ethanol yield (\%) & $* * *$ & $* * *$ & 1.00 & $* * *$ & $* * *$ & 1.00 \\
\hline
\end{tabular}

\section{Conclusion}

The study revealed that flours and starches produced from the three cassava varieties used are suitable for ethanol production. They were found to have good qualities in terms of high amylose content where ethanol is dependent on it. However, cassava variety TMS 98/0505 stands out as it starch showed a high potential for ethanol production. 


\section{References}

1. N, Nadir,M, Mel,MIA, Karim and RM,Yunus.Comparison of sweet sorghum and cassava for ethanol production using Saccharomyces cerevisiae. J. Applied Sci.,2009. 9: p3068-3073

2. C, Alais C andG,Linden. Food Biochemistry, Aspen Publishers Inc. Coaistherburg Maryland, 1999 p. 4

3. J, Baras, S, Gaãeša, D, Pejin.Ethanol is strategic raw material, Chem. Ind. 2002 56: 89-105

4. A, Demirbas. Progress and recent trends in biofuels, Progres in Energy and Combustion Science, doi: 10.1016/jpecs.2006. 06. 001

5. A, Rosenberger.Improving the energy balance of bio-ethanol production from winter cereals: the effect of crop production intensity. Applied Energy, 2001. 68(1): 51-67.

6. A, Hansen, Q, Zhang and P, Lyne. Ethanol-diesel fuel blends-a rewiew, Bio-Recourse Technology 200596, 277285

7. HA, Etudaiye, E, Oti, T, Sanchez, RM, Omodamiro, OS, Afuape and A, Ikpeama. Effect of variety and influence of granular starch hydrolyzing enzyme and yeast on the yield of ethanol generated from cassava flours and starches. Pelagia Research Library. Advances in Applied Science Research 20123 (5) 2774-2778.

8. AGO, Dixon, RU, Okechukwu, M, Akoroda, P, Ilona, F, Ogbe, J, Mkumbira, G, Ssemakula, L, Sanni, J, Lemchi, E, Okoro, C, Ezedinma, M, Patino, G, Tarawali, B, Maziya-Dixon, C, Goteloma. New cassava variety FlyerTMS 98/0581, 2005IITA Integrated Cassava Project. Ibadan, Nigeria.

9. H, Ceballos, T, Sanchez, N, Morante, M, Fregene, D, Dufour, SM, Smith, K, Denyer,JC,Perez, F, Calle and C, Mestres. Discovery of an Amylose-free Starch Mutant in Cassava (Manihot esculenta Crantz). J. of Agric. And Food Chem.2007

10. L, Sanni, B, Maziya-Dixon B, Akanya J, Okoro CI,Alaya, Y, Egwuonwu CV., Okechukwu RU., Ezedinma C, Akoroda M, Lemchi L, Ogbe F, Okoro E, Tarawali G, Mkumbira J, Patino M, Ssemakula G and Dixon A Standards for cassava products and guidelines for export 2005 International Institute of Tropical Agriculture, Ibadan, Nigeria

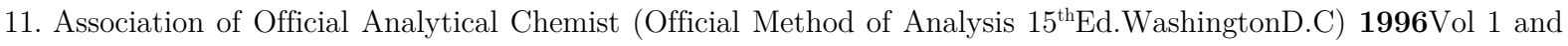
2 .

12. OB, Oluwole, OO, Olatunji, SA, Odunfa. A Process Technology for Conversion of Dried Cassava Chips into "Gari". Nigerian Food Journal 200422: 65-77.

13. CC, Okoro. Effect of process modification on the physio-chemical and sensory quality of fufu-flour and dough. African Journal of Biotechnology 6: 20071949-1953.

14. PC,Williams, FD, Kuzina,IA, Hlynka.Cereal Chem. 1970, 47, 411-420.

15. GL, Miller. Use of dinitrosalicylic acid reagent for determination of reducing sugar, Anal. Chem.,195931, 426, 1959.

16. Statistical Analytical System (SAS): copyright (C) 2009 SAS Institute Inc.; Cary NC, USA

17. E, Nuwamanya, Y, Baguma,, N, Emmambux, J, Taylor and P, Rubaihayo. Physicochemical and functional characteristics ofcassava starch in Ugandan varieties and their progenies.Journal of Plant Breeding and Crop Science 2010 Vol. 2(1).1-11

18. E, Nuwamanya, Y, Baguma, N, Emmambux, J, Taylor and P, Rubaihayo.Crystalline and pasting properties of cassava starch are influenced by its molecular properties African Journal of Food Science 2010Vol 4(1) 8-15

19. I, Defloor, I, Dehing, JA, Delcour. Physico-chemical properties of cassava starch. Starch/Stärke1998, 50, 58-64

20. A, Fernandez, J, Wenham, D, Dufour, CC,Wheatley. The influence of variety and processing on the physicochemical and functional properties of cassava starch and flour. In Cassava Flour and Starch: Progress in Research and Development;Dufour, D., O'Brien, G. M., Best R., Eds.; CIRAD/CIAT Montpellier France/ Cali Colombia: 1996pp 263-269.

21. FO, Ajibola, MO, Edema and OB, Oyewole.Enzymatic production of ethanol from cassava of starch using two strains of Saccharomyces cereviciae. In Nig. Food Jr. 2012 Vol 30, Isuue 2 114-121

22. S, Moorthy. Physicochemical and functional properties of tropical tuber starches: A review. Starch 54: 2002 559-562

23. YC, Shi, T, Capitani, P, Trzasko and R, Jeffcoat. Molecular structure of low- amylopectin starch and other high- amylose maize starches. J. Cereal Sci 1998 27: 289-299 